\title{
Nutritional Characteristics of Rice (Oryza sativa L.) Composite Flours Obtained by Food Fortification
}

\author{
Violet K. Mugalavai, Kevin O. Aduol, and Augustino O. Onkware
}

\section{ABSTRACT}

High prevalence of protein-energy malnutrition among the vulnerable population, especially children has prompted research on fortification of common staple cereal foods such as rice. However, rice has inferior nutritional value compared to other popular cereals, such as maize, therefore limiting its full utilization. Its storage protein, glutelins, is not easily digested by monogastric animals; therefore, food to food fortification of rice flours provides protein nutritional compensation as well as improvement of other nutrients. This study was carried out to determine the proximate and mineral $(\mathrm{Fe}, \mathrm{Zn}, \mathrm{Mg}, \mathrm{Ca}, \mathrm{P})$ composition of rice composite flours. Methodology: The blending ratios (rice: maize: sorghum: pumpkin: carrots: baobab: amaranth) used in the study were 70:0:0:7.5:7.5:5:10 (AT1), 45.5:24.5:0:7.5:7.5:5:10 (AT2), 35:35:0:7.5:7.5:5:10 (AT3), 23.3:23.3:23.3:7.5:7.5:5:10 (AT4) and 100\% rice flour (AT5). Proximate analyses were performed according to Association of Official Analytical Chemist (AOAC) methods. Atomic absorption spectroscopy was used to determine the minerals. Data analysis was done using Analysis of Variance (ANOVA). Mean comparisons for treatments were done using Bonferroni tests and significance level was set at $\mathbf{P} \leq \mathbf{0 . 0 5}$. Findings: Moisture content of the composite flours ranged from 10.87 to12.55\% and was significantly different $(p<0.05)$. Ash content was not significantly different $(p<0.05)$ and ranged between 1.08 and $1.85 \%$. The fat content ranged between 5.38 and $10.67 \%$; with AT4 having the highest and AT5 having the least fat content. The carbohydrate content was significantly $(p<0.05)$ different among the flour; ranging between 66.65 and $\mathbf{7 3 . 5 1 \%}$. Crude fibre ranged between 1.42 and $-\mathbf{2 . 2 0 \%}$, whereas the protein content ranged from 6.88 to $7.73 \%$. Iron content ranged between 0.06 and $0.08 \mathrm{mg} / 100 \mathrm{~g}$ zinc ranged from 0.19 to $0.56 \mathrm{mg} / 100 \mathrm{~g}$. The phosphorus content ranged from 0.07 to $0.18 \mathrm{mg} / 100 \mathrm{~g}$ with no significant $(p<0.05)$ difference. The calcium content was significantly $(p<0.05)$ different among the flours and ranged from 1.41 to $1.91 \mathrm{mg} / 100 \mathrm{~g}$. Conclusion: The results show that the flour composites have the potential to improve nutritional status of consumers. Thus, consumption of AT1, AT4 and AT5 composite flours with a protein content of $7.3 \%, 7.7 \%$ and 7.4\% maybe recommended for children aged $6-59$ months in order to prevent protein-energy malnutrition.

Keywords: rice flours, proximate, composites, value-added.
Published Online: January 25, 2021

ISSN: $2684-1827$

DOI: $10.24018 /$ ejfood.2021.3.1.224

\section{Violet K. Mugalavai}

Department of Family and Consumer Sciences, \& Laboratory of Food Processing Training and Incubation Centre, University of Eldoret, Kenya.

(e-mail: violet.mugalavai @gmail.com)/ (violet.mugalavai@uoeld.ac.ke)

Kevin O. Aduol*

Department of Family and Consumer Sciences, University of Eldoret, Kenya. (e-mail: $\quad$ komondi @ ${ }^{\circledR}$ uoeld.ac.ke)/ kevinaduol@yahoo.com)

Augustino O. Onkware

School of Science, Rongo University, Kenya.

(e-mail: aonkware@yahoo.com)

*Corresponding Author

\section{INTRODUCTION}

Rice (Oryza sativa L.) is a staple food for more than a third of the world's population [1], [2] especially in Africa [3], [4]. In Kenya, rice is currently the third most important staple cereal after maize and wheat [3] and for low income consumers, rice accounts for $3.9 \%-4.8 \%$ of total food expenditure compared to $13.5 \%$ and $9.7 \%$ for maize and wheat, respectively [5]. Rice consumption in Kenya keeps growing at $11 \%$ every year since independence and this is attributed to population growth, urbanization and change in consumer habits [3], [4], [6]. Currently, Kenya produces about 150,000 metric tons from about 25,000 hectares of land [7]. This meets only about $20 \%$ of the total demand as annual rice consumption is about 550,000 metric tons [6], [7]. However, rice has inferior nutritional value compared to other popular cereals such as maize, therefore limiting its full utilization [8]. This inferiority is partly because it is majorly composed of starch (approximately 80\%-85\%), $4 \%-10 \%$ protein, $1 \%$ lipid and $10 \%$ moisture [9]. Also, its storage protein, glutelins, is not easily digested by monogastric animals [10]. This has therefore necessitated food to food fortification of rice flours to improve on bioavailability of micronutrients as well as the protein quality [11]. Composites are mainly done with legumes which are rich in lysine, with a cereal that contains a relatively good concentration of sulphur-containing amino acids, resulting in protein nutritional compensation [12]. Rice is mostly consumed as cooked grains but can also be processed into flour and used to make various beneficial products since its gluten free, low in calcium and lacks most of the allergic proteins [1], [8], [13], [14]. Globally, rice is mainly used for production of noodles, sweets, and desserts [15]. It is also an excellent thickener for custards, gravies, 
and sauces [16]. Rice flour is also used as thickening agent in refrigerated or frozen recipes since it inhibits liquid separation [11], [17]. Its low-allergenic properties also make it suitable for infants [8], [18]. Rice has other unique functional properties such as flavor carrying capability, hypo-allergenicity and bland flavor, making them desirable for use in value-adding products. Despite all these advantages, rice is deficient of some nutrients: it has weak functional proteins, $80 \%$ glutelin, which is not very soluble in water [13], [19]. To enhance rice production and hence boost food and nutrition security, Kenya's policy makers must understand the impediments that exist across the rice value chain and import process and explore the opportunities that may exist within the value chain such as value addition. This study was designed to determine the proximate and mineral characteristics of rice composite flours containing different proportions of a variety of other nutrient-rich foods.

\section{MAterials AND MethodS}

\section{A. Sample Acquisition}

The raw materials were sourced from different parts of Kenya. Maize was obtained from Eldoret market located in the Rift Valley region of Kenya. Pale-red sorghum (E97) and pale cream amaranth grain were obtained from Busia and Bungoma, Western Kenya. Baobab powder was obtained from Mombasa and the sweet potato puree was obtained from Organi Limited in Homabay, Kenya. The rice used in the study was the Kenyan variety Mwea Pishori rice. The dried foodstuffs were stored at $25{ }^{\circ} \mathrm{C}$ and the potato puree was stored in a deep freezer at $-20^{\circ} \mathrm{C}$. The cereals were washed and dried whereas the vegetable sources were pealed and blanched at $75{ }^{\circ} \mathrm{C}$ for 5 minutes [20], [21] before grating. They were then dried using Kleins Dehy-Tray (JUA Technologies International, USA) at $75^{\circ} \mathrm{C}$ for 6 hours.

\section{B. Preparation of Compositing Flours}

Milling of the ingredients was individually done in a laboratory grinder (Bountiful International, USA) to obtain the flours. The flours were sieved, immediately packaged in airtight containers and stored in a cool and dry place at room temperatures $\left(\sim 25^{\circ} \mathrm{C}\right)$ until use [20].

\section{Formulation of Value-added Composites}

Four composites $\left(\mathrm{AT}_{1}, \mathrm{AT}_{2}, \mathrm{AT}_{3}\right.$ and $\left.\mathrm{AT}_{4}\right)$ were prepared with a variation in the rice, maize and sorghum cereals used. Composite $\mathrm{AT}_{5}(100 \%$ rice flour) was used as the control (Table 1).

TABLE 1: COMPOSITION OF COMPOSITE FLOURS

\begin{tabular}{cccccc}
\hline \multicolumn{5}{c}{ TABLE 1: COMPOSITION OF COMPOSITE FLOURS } \\
\cline { 2 - 6 } Ingredients & $\mathrm{AT}_{1}$ & $\mathrm{AT}_{2}$ & $\mathrm{AT}_{3}$ & $\mathrm{AT}_{4}$ & $\mathrm{AT}_{5}$ \\
\hline Rice & 70 & 45.5 & 35 & 23.3 & 100 \\
Maize & - & 24.5 & 35 & 23.3 & - \\
Sorghum & - & - & - & 23.3 & - \\
Pumpkin & 7.5 & 7.5 & 7.5 & 7.5 & - \\
Carrots & 7.5 & 7.5 & 7.5 & 7.5 & - \\
Baobab & 5 & 5 & 5 & 5 & - \\
Amaranth & 10 & 10 & 10 & 10 & - \\
Total & 100 & 100 & 100 & 100 & 100 \\
\hline
\end{tabular}

\section{Reagents for Analysis}

All the chemicals used for proximate and mineral analyses were of analytical grade from Sigma Chemicals Co. (St, Louis, MO, USA). These included n-hexane, sulphuric acid, nitric acid, sodium hydroxide, hydrogen peroxide, hydrochloric acid, boric acid, mix indicator and standards of minerals.

\section{E. Proximate Analysis of Rice Composite Flours}

Proximate analysis: ash, fats, moisture, crude fiber and protein content were performed according to Association of Official Analytical Chemist official methods; 923.03, 925.09, 978.10 and 979.09 [22]. Moisture content was determined by the oven method; protein content was determined by Kjeldahl method (nitrogen content $\times 6.25$ ); fat content was determined by petroleum ether extraction; and crude fiber was determined by digesting defatted samples with diluted (1.25\%) sulfuric acid solution for 30 mins at boiling point followed by digestion with $1.25 \%$ sodium hydroxide solution for the same 30 mins [12], [23], [24]. The carbohydrate content was determined as difference between 100 and total sum of the percentage of ash, moisture, fiber, fat and protein [25]. All analyses were performed in triplicates.

\section{F. Mineral Analysis of Rice Composite Flours}

Atomic absorption spectroscopy (AAS AA-7000, Shimadzu Cop. Japan) was used to determine the minerals; iron, zinc, calcium, phosphorus and magnesium. Approximately $2.0 \mathrm{~g}$ of flour composites were weighed and transferred into a digestion flask, to this $5.0 \mathrm{~mL}$ concentrated nitric acid was added [26]. The flasks were heated at $80-90{ }^{\circ} \mathrm{C}$ for $2 \mathrm{~h}$ to digest. The temperature was then raised to $170-180{ }^{\circ} \mathrm{C}$ and $3-5 \mathrm{~mL}$ of each of the hydrogen peroxide and sulphuric acid (concentrated) were added and heating continued until the material was completely digested [25]. The digest was then transferred to a $50 \mathrm{~mL}$ volumetric flask and the volume made up to the mark with deionized water. Primary standard solutions of $\mathrm{Mg}, \mathrm{Ca}, \mathrm{Fe}, \mathrm{P}$ and $\mathrm{Zn}$ were prepared and diluted successively to obtain required series of solutions for construction of standard calibration curve [22].

\section{G. Data Analysis}

Data analysis was done using Analysis of Variance (ANOVA) with Stata $\subset$ version 12. Mean comparisons for treatments were done using Bonferroni tests. Significance level was set at $\mathrm{P} \leq 0.05$.

\section{RESULTS AND DISCUSSION}

\section{A. Proximate Composition}

Results of proximate composition are presented in Table 2. Moisture content was significantly different $(\mathrm{p}<0.05)$ among the composites; with the lowest level (10.9\%) being in AT5 and the highest (12.6\%) in AT2. These values are similar those reported by [2], [27], [48]. However, the values are slightly higher than those reported by [14], [15], [28]-[30]. The high moisture level of AT2 could be attributed to the drying temperature used [31]. Composites, such as AT4 and AT5 that had low moisture content have 
potential for long storage [11]. The significant difference observed in the moisture content of the flour composites may be attributed to temperature and duration of drying. The Moisture content of food is influenced by the type of food, food variety, and storage conditions [28]. Flours with moisture content above 14 percent are $t$ often no stable at room temperature and may spoil easily and the relative high moisture content may reduce the shelf life of the composite flour: food materials, such as flour, containing more than $12 \%$ moisture have lesser storage stability than those with lower moisture content [32].

The ash content of the composite flours ranged between $1.08-1.85 \%$, with no significant difference $(\mathrm{p}<0.05)$ among the sample composites. Composite AT3 had the highest ash content of $1.85 \%$ (Table 1) while composite AT5 had the least ash content of $1.08 \%$. These results are close to those reported by [2], [15], [33]. The values are also similar to those reported by [16], [26], [28], [30]. The ash content of a food sample is indicative of the mineral elements present in the food sample [34]. Minerals are more concentrated in the bran and thus get lost during milling and polishing [42]. The low ash content observed in the other varieties may be due to the degree of milling/polishing.

The fat content obtained ranged between $5.38-10.67 \%$ with AT4 having the highest fat content and AT5 having the least fat content (Table 2). The values are close to the range reported by [15], but higher than those reported by [2] There was observed significant difference in fat content $(\mathrm{p}<0.05)$ which could be attributed to the different proportions of sorghum used. Milling and polishing of rice removes the outer layer of the grain where most of the fats are concentrated [36].

Carbohydrate content ranged between $66.65-73.51 \%$ and statistical analysis showing significant difference $(\mathrm{p}<0.05)$. These values correspond closely to that reported by [2], [15], [16], [30], [33], [44], [48]. [2] reported carbohydrate content range between $74.20-79.41 \%$, whereas [33] reported values ranging between $78.3 \%$ and $81.1 \%$.
The range of values for crude fibre observed in this study was between $1.42-2.20 \%$ for the five rice flour composites (Table 2). These values are almost similar to $0.5-1.95 \%$ reported by [2]. [27] reported slightly lower crude fibre values ranging between $0.59-0.89 \%$ for different varieties of rice. [15] reported crude fibre range of $0.99-1.01 \%$, which is slightly lower than the results of the present study. Statistical analysis did not reveal any significant difference $(\mathrm{p}<0.05)$ in the crude fibre values for the rice flour composites. Milling of rice during the production of polished rice generally decreases the fibre contents; hence the relatively low fibre in the imported brands [41]. The bran is particularly rich in dietary fibre and contains significant quantities of starch [47] which also contributes to the carbohydrate content of brown rice. The observed difference may be due to the fact that the imported rice brands are more polished than the local varieties. Percentage carbohydrate could also be influenced by other environmental factors under which rice is grown (soil type, crop management practices, rainfall, solar radiation, and growth temperature) [41].

The protein content of the rice flour composites ranged from 6.88-7.73\% (Table 2). Composite AT3 had the lowest protein content $(6.88 \%)$ while composite AT4 had the highest protein content, although statistical analysis showed no significant difference $(\mathrm{p}<0.05)$ in protein contents among the composites. These findings are in the range of values reported by [2], [15], [39], [44], [48]. However, these findings were higher than the findings reported by [34] a range of 5.10-5.30\%. [38], [40] reported that deposition of protein in rice grains depends on plethora of interrelated metabolic pathways involved in uptake of $\mathrm{N}, \mathrm{Fe}$ and $\mathrm{Zn}$ from soil, their transport to source tissues such as culms and leaves and mobilization and/or remobilization to developing grains. Each of these processes is governed by several genes and influenced by environmental factors such as soil type, drought, fertilizers application, genotype and environment interaction [37], [50].

TABLE 2: PRoXimATE COMPOSITION OF VALUE-AdDED Rice FLOUR COMPOSITES

\begin{tabular}{ccccccc}
\hline \multirow{2}{*}{ Sample } & \multicolumn{5}{c}{ \%Composition } \\
\cline { 2 - 6 } & Moisture & Fat & Ash & Proteins & Fiber & Carbohydrate \\
\hline AT1 & $12.00 \pm 0.26^{\mathrm{a}}$ & $8.00 \pm 0.98^{\mathrm{bd}}$ & $1.78 \pm 0.14^{\mathrm{a}}$ & $7.30 \pm 0.09^{\mathrm{a}}$ & $1.90 \pm 0.19^{\mathrm{a}}$ & $68.59 \pm 1.02^{\mathrm{a}}$ \\
AT2 & $12.55 \pm 0.28^{\mathrm{b}}$ & $7.13 \pm 0.57^{\mathrm{a}}$ & $1.82 \pm 0.15^{\mathrm{a}}$ & $6.94 \pm 0.30^{\mathrm{a}}$ & $1.42 \pm 0.08^{\mathrm{a}}$ & $71.14 \pm 1.03^{\mathrm{bd}}$ \\
AT3 & $12.13 \pm 0.19^{\mathrm{ab}}$ & $9.20 \pm 0.28^{\mathrm{c}}$ & $1.85 \pm 0.24^{\mathrm{a}}$ & $6.88 \pm 0.27^{\mathrm{a}}$ & $2.20 \pm 0.38^{\mathrm{a}}$ & $67.74 \pm 0.46^{\mathrm{ad}}$ \\
AT4 & $11.87 \pm 0.13^{\mathrm{ac}}$ & $10.67 \pm 0.21^{\mathrm{a}}$ & $1.68 \pm 0.10^{\mathrm{a}}$ & $7.73 \pm 0.57^{\mathrm{a}}$ & $1.83 \pm 0.13^{\mathrm{a}}$ & $66.65 \pm 0.58^{\mathrm{a}}$ \\
AT5 & $10.87 \pm 0.19^{\mathrm{a}}$ & $5.38 \pm 0.48^{\mathrm{abd}}$ & $1.08 \pm 0.22^{\mathrm{a}}$ & $7.38 \pm 1.07^{\mathrm{a}}$ & $1.78 \pm 0.18^{\mathrm{a}}$ & $73.51 \pm 1.06^{\mathrm{a}}$ \\
\hline
\end{tabular}

Values are mean \pm standard deviations of triplicates. Values with different letter superscript in the same column are significantly different at ( $<0.05$ ) based on Bonferroni tests.

\section{B. Mineral Composition}

Table 3 shows the mineral content of five (5) of the rice flour composites. Iron content ranged between 0.06$0.08 \mathrm{mg} / 100 \mathrm{~g}$. Composites AT3 and AT5 had the least iron content while composites AT1 and AT4 had the highest iron content. There was no significant difference $(\mathrm{p}<0.05)$ in iron content of the composite flours (Table 2). The values of iron obtained were much higher than that reported by [2], [33], [35]. This low iron content may be due to milling that interfered with bran particularly rich in dietary minerals such as iron. The difference in iron content among the rice varieties may also be influenced by nitrogen application and soil quality [46].

The magnesium content of the flour composites ranged from 1.26-5.58 mg/100 $\mathrm{g}$ with a significant difference $(\mathrm{p}<0.05)$ (Table 3). These values are much lower than that reported by [2], [33]. The local intra varietal differences could be due to genetic factors or the mineral content of the soil on which they were grown [42]. In general, the more rice bran is removed from the grain during polishing, the more minerals are lost [41]. 
The zinc values obtained in this study ranged from 0.19 $0.56 \mathrm{mg} / 100 \mathrm{~g}$ (Table 3 ). These values are slightly lower than earlier findings by [45] who found a range of 1.40 to $1.79 \mathrm{mg} / 100 \mathrm{~g}$ and $1.97 \mathrm{mg} / 100 \mathrm{~g}$ reported by [49]. [2] reported a range of 1.05 to $2.9 \mathrm{mg} / 100 \mathrm{~g}$, which is also slightly higher than the values in this present study. Phosphorus content of the rice flour composites ranged from $0.07-0.18 \mathrm{mg} / 100 \mathrm{~g}$ with no significant difference $(\mathrm{p}<0.05)$. The calcium content of the composites ranged from 1.41$1.91 \mathrm{mg} / 100 \mathrm{~g}$ with significant difference $(\mathrm{p}<0.05)$.

The chemical composition (nutrients) of rice grain varies considerably depending on factors like plant variety (breeds), environmental condition (i.e. location and season in which grown), fertilizer treatment, degree of milling, and condition of storage [43]. As with all natural foods, the precise nutritional composition of rice varies depends on the variety, soil conditions, environmental conditions and types of fertilizers.

TABLE 3: Mineral COMPOSITION OF VALUE-AdDED Rice Flour COMPOSITES

\begin{tabular}{cccccc}
\hline Sample & \multicolumn{4}{c}{ Mineral elements $(\mathrm{mg} / 100 \mathrm{~g})$} \\
\cline { 2 - 6 } & Phosphorus & Zinc & Iron & Calcium & Magnesium \\
\hline AT1 & $0.14 \pm 0.01^{\mathrm{a}}$ & $0.56 \pm 0.03^{\mathrm{ab}}$ & $0.08 \pm 0.00^{\mathrm{a}}$ & $1.91 \pm 0.08^{\mathrm{a}}$ & $3.20 \pm 0.01^{\mathrm{a}}$ \\
AT2 & $0.18 \pm 0.10^{\mathrm{a}}$ & $0.22 \pm 0.01^{\mathrm{a}}$ & $0.07 \pm 0.01^{\mathrm{a}}$ & $1.41 \pm 0.01^{\mathrm{b}}$ & $1.26 \pm 0.02^{\mathrm{a}}$ \\
AT3 & $0.14 \pm 0.03^{\mathrm{a}}$ & $0.37 \pm 0.04^{\mathrm{cd}}$ & $0.06 \pm 0.01^{\mathrm{a}}$ & $1.57 \pm 0.03^{\mathrm{bd}}$ & $2.97 \pm 0.04^{\mathrm{b}}$ \\
AT4 & $0.14 \pm 0.01^{\mathrm{a}}$ & $0.36 \pm 0.04^{\mathrm{c}}$ & $0.08 \pm 0.01^{\mathrm{a}}$ & $1.45 \pm 0.02^{\mathrm{bc}}$ & $3.36 \pm 0.03^{\mathrm{a}}$ \\
AT5 & $0.07 \pm 0.02^{\mathrm{a}}$ & $0.19 \pm 0.02^{\mathrm{e}}$ & $0.06 \pm 0.01^{\mathrm{a}}$ & $1.64 \pm 0.02^{\mathrm{c}}$ & $5.58 \pm 0.23^{\mathrm{c}}$ \\
\hline
\end{tabular}

Values are mean \pm standard deviations of triplicates. Values with different letter superscript in the same column are significantly different at $(p<0.05)$ based on Bonferroni tests.

\section{CONCLUSION AND RECOMMENDATION}

The results from the study show that food to food fortification approaches result into a nutrient enhanced rice composite flours which maybe suitable for both home and industrial applications. Therefore the study recommends a consumer acceptability study to evaluate consumer preference and acceptability. This shall lead to popularization and adaptability by the caregivers to enhance food and nutrition diversity and protein energy malnutrition prevalence reduction.

\section{ACKNOWLEDGMENT}

This work was funded in whole by the United States Agency for International Development (USAID) Bureau for Food Security under Agreement number AID-OAA-L-1400003 as part of Feed the Future Innovation Lab for Food Processing and Post-harvest Handling and National Research Foundation Kenya Project No. 46/2018. Any opinions, findings, conclusions, or recommendations expressed here are those of the authors alone.

\section{REFERENCES}

[1] F. G. Horgan, F. A. Ramal, C. C. Bernal, J. M. Villegas, A. M. Stuart \& M. L. P Almazan. (2016). Applying ecological engineering for sustainable and resilient rice production systems. Procedia Food Science, 6(Icsusl International Conference of Sabaragamuwa
University of Sri Lanka 2015 (ICSUSL 2015)), 7-15. https://doi.org/10.1016/j.profoo.2016.02.002.

[2] F. D. Wireko-manu \& C. Amamoo. (2017). Comparative Studies on Proximate and Some Mineral Composition of Selected Local Rice Varieties and Imported Rice Brands in Ghana. Agriculture and Food Sciences Research, 4(1), 1-7. https://doi.org/10.20448/journal.512.2017.41.1.7.

[3] E. A. Atera, F. N. Onyancha \& E. B. O. Majiwa. (2018). Production and marketing of rice in Kenya: Challenges and opportunities. Journal of Development and Agricultural Economics, 10(3), 64-70. https://doi.org/10.5897/JDAE2017.0881.

[4] FAO. (2012). Analysis of Incentives and Disincentives for Rice in Kenya, (December). Retrieved from www.fao.org/mafap.

[5] Ministry of Agriculture. (2018). National Rice Development Strategy (2008 - 2018). Republic of Kenya.

[6] E. A. Atera, J. C. Onyango, T. Azuma, S. Asanuma, \& K. Itoh. (2011). Field evaluation of selected NERICA rice cultivars in Western Kenya. African Journal of Agricultural Research, 6(1), 6066. https://doi.org/10.5897/AJAR09.516.

[7] Kenya Bureau of Statistics, (2016). Economic Survey 2016. Nairobi, Kenya, 144-165.

[8] E. M. Blase. (2020). Optimisation of Rice Flour Traits for the Production of Indigenous Rice Recipes. Current Research in Nutrition and Food Science, 08(1), 349-359. Retrieved from www.foodandnutritionjournal.org.

[9] J. L. Balindong, R. M. Ward, L. Liu, T. J. Rose, L. A. Pallas, B. W. Ovenden, P. J. Snell, D. L. E. Waters. 2018. Rice grain protein composition influences instrumental measures of rice cooking and eating quality. J Cereal Sci, 79: 35-42.

[10] F. Takaiwa, M. Ogawa, T. W. Okita (1999) Rice Glutelins. In: P. R.Shewry, R. Casey (eds) Seed Proteins. Springer, Dordrecht. https://doi.org/10.1007/978-94-011-4431-5_17.

[11] S. Chandra \& Samsher. (2013). Assessment of functional properties of different flours. African Journal of Agricultural Research, 8(38), 4849-4852. https://doi.org/10.5897/AJAR2013.6905.

[12] V. K. Mugalavai, J. O. Oyalo, \& A. O. Onkware (2020). Characterization of The Nutritional Properties of Sorghum Composite Flours Using Different Food to Food Fortification Approaches. European Journal of Agriculture and Food Sciences, 2(6), 1-7.

[13] X. Li, Y. Liu, N. Li, D. Xie, J. Yu, F. Wang \& J. Wang (2016). Studies of phase separation in soluble rice protein / different polysaccharides mixed systems. LWT-Food Science Technology, 65, 676-682.

[14] C.K. Reddy, L. Kimi, S. Haripriya \& N. Kang (2017). Effects of Polishing on Proximate Composition, Physico-Chemical Characteristics, Mineral Composition and Antioxidant Properties of Pigmented Rice. Rice Science, 24(5), 241-252. https://doi.org/10.1016/j.lwt.2015.08.064.

[15] H. Twinomuhwezi, C. G. Awuchi \& M. Rachael (2020). Comparative Study of the Proximate Composition and Functional Properties of Composite Flours of Amaranth, Rice, Millet, and Soybean. American Journal of Food Science and Nutrition, 6(1), 6-19.

[16] U. G. Ojali, A. U. Elijah, A. O. Nicholas \& B. R. Morayo (2015). Proximate Composition and Anti-nutrient Properties of Breakfast Cereal Made from Blends of Local Rice, Soybeans and Defatted Coconut Flours. Journal of Nutrition \& Food Sciences, 11(ISSN: 2155-9600), 8-10. https://doi.org/10.4172/2155-9600.1000S11006.

[17] U. E. Inyang, C. F. Effiong \& A. P. Edima-nyah (2018). Physical Properties, Nutritional Composition and Sensory Evaluation of Cookies Prepared from Rice, Unripe Banana and Sprouted Soybean Flour Blends. International Journal of Food Science and $\begin{array}{rrr}\text { Biotechnology, } & 3(2), & 70-76 .\end{array}$ https://doi.org/10.11648/j.ijfsb.20180302.15

[18] B. O. Juliano (1991). Rice in Human Nutrition. International Rice Research Institute, 26(1).

[19] S. Mohammad \& T. Gharibzahedi (2018). Favorite and traditional rice flour e based puddings, breads, and pastries in the north of Iran : A review. Journal of Ethnic Foods, 5(2), 105-113. https://doi.org/10.1016/j.jef.2018.03.001

[20] J. Pongjanta, A. Naulbunrang, S. Kawngdang, T. Manon \& T. Thepjaikat (2006). Utilization of pumpkin powder in bakery products. Songklanakarin J. Sci. Technol., 28(March), 71-79.

[21] J. K. Kikafunda, L. Abenakyo \& F. B. Ludwig (2006). Nutritional and Sensory Properties of High Energy / Nutrient Dense Composite Flour Porridges from Germinated Maize and Roasted Beans for ChildWeaning in Developing Countries : A Case for Uganda. Ecology of Food and Nutrition, (45), 279-294. https://doi.org/10.1080/03670240600846344. 
[22] AOAC, Official Methods of Analysis of AOAC International, 17th edn. (Association of Official Analytical Chemists (AOAC) International, Gaithersburg, 2000).

[23] C. Anino, A. N. Onyango, S. Imathiu, J. Maina \& F. Onyangore (2019). Chemical composition of the seed and 'milk' of three common bean (Pharsalus vulgaris L) varieties. Journal of Food $\begin{array}{llll}\text { Measurement and Characterization, } & 0(0), & 0\end{array}$ https://doi.org/10.1007/s11694-019-00039-1.

[24] K. O. Aduol, A. N. Onyango \& S. Imathiu (2020). Proximate, Microbial and Sensory Characteristics of Cowpea Milk Fermented with Probiotic Starter Cultures. European Journal of Agriculture and Food Sciences, 2(4), 2.

[25] M. A. Zubair, M.S. Rahman, M.S. Islam, M. Z. Abedin \& M. A. Sikder (2015). A Comparative Study of the Proximate Composition of Selected Rice Varieties in Tangail, Bangladesh. J. Environ. Sci. \& $\begin{array}{lll}\text { Natural } & \text { Resources, } & \text { 8(2), }\end{array}$ https://doi.org/10.3329/jesnr.v8i2.26874.

[26] D. K. Verma \& P. P. Srivastav (2017). Proximate Composition, Mineral Content and Fatty Acids Analyses of Aromatic and NonAromatic Indian Rice. Rice Science, 24(1), 21-31. https://doi.org/10.1016/j.rsci.2016.05.005.

[27] G. Eshun (2009). Baseline data on the nutrient content and physicochemical properties of selected varieties of soybean, groundnut and rice for the development of nutritious, energy-dense diets.

[28] C. G. Awuchi (2019). Proximate Composition and Functional Properties of Different Grain Flour Composites for Industrial Applications. International Journal of Food Sciences (IJF), 2(1), 4364.

[29] S. Chandra, S. Singh \& D. Kumari (2015). Evaluation of functional properties of composite flours and sensorial attributes of composite flour biscuits. J Food Sci Technol, 52(6), 3681-3688. https://doi.org/10.1007/s13197-014-1427-2.

[30] M. Iwe, U. Onyeukwu \& A. N. Agiriga (2016). Proximate, functional and pasting properties of FARO 44 rice, African yam bean and brown cowpea seeds composite flour. Cogent Food \& Agriculture, 2, 1-10. https://doi.org/10.1080/23311932.2016.1142409.

[31] X. Zheng \& Y. Lan (2007). Effects of Drying Temperature and Moisture Content on Rice Taste Quality. Agricultural Engineering International: The CIGR Ejournal, IX (November), 1-9.

[32] B. I. Offia-olua (2014). Chemical, Functional and Pasting Properties of Wheat (Triticumspp) -Walnut (Juglansregia) Flour. Food and Nutrition Sciences, 5(August), 1591-1604.

[33] O. A. T. Ebuehi \& A. C. Oyewole (2007). Effect of cooking and soaking on physical characteristics, nutrient composition and sensory evaluation of indigenous and foreign rice varieties in Nigeria. African Journal of Biotechnology, 6(8), 1016-1020.

[34] E. Adu-kwarteng, W.O. Ellis, I. Oduro \& J. T. Manful (2003). Rice grain quality : a comparison of local varieties with new varieties under study in Ghana. Food Control, 14, 507-514. https://doi.org/10.1016/S0956-7135(03)00063-X.

[35] C. Diako, E. Sakyi-dawson, B. Bediako-Amoa, F.K Saalia \& J. T. Manful (2010). Consumer Perceptions, Knowledge and Preferences for Aromatic Rice Types in Ghana. Nature and Science, 8(12), 12-19.

[36] M. Frei, P. Siddhuraju \& K. Becker (2003). Studies on the in vitro starch digestibility and the glycemic index of six different indigenous rice cultivars from the Philippines. Food Chemistry, 83, 395-402. https://doi.org/10.1016/S0308-8146(03)00101-8.

[37] G. B. Gregorio (2002). Progress in Breeding for Trace Minerals in Staple Crops. American Society for Nutritional Sciences, (March), 500-502.

[38] M. A. Grusak (2013). Enhancing Mineral Content in Plant Food Products. Journal of the American College of Nutrition, 21(3), 178183. https://doi.org/10.1080/07315724.2002.10719263.

[39] K. O. Jimoh \& O. P. Olatidoye (2009). Evaluation of physicochemical and rheological characteristics of soybean fortified yam flour. Journal of Applied Biosciences, 13, 703-706.

[40] A. A. Mahmoud, S. Sukumar \& H. B. Krishnan (2008). Interspecific Rice Hybrid of Oryza sativa $\times$ Oryza nivara reveals a Significant Increase in Seed Protein Content. Journal of Agricultural and Food Chemistry, 56(2), 476-482. https://doi.org/10.1021/jf071776n.

[41] A. O. Oko \& S. I. Ugwu (2011). The proximate and mineral compositions of five major rice varieties in Abakaliki, South-Eastern Nigeria. International Journal of Plant Physiology and Biochemistry, 3(2), 25-27.

[42] M. Rivero-huguet, R. Huertas, L. Francini, L.Vila, E. Darré \& L. Tecnológico (2006). Concentrations of $\mathrm{As}, \mathrm{Ca}, \mathrm{Cd}, \mathrm{Co}, \mathrm{Cr}, \mathrm{Cu}, \mathrm{Fe}$ , $\mathrm{Hg}, \mathrm{K}, \mathrm{Mg}, \mathrm{Mn}, \mathrm{Mo}, \mathrm{Na}, \mathrm{Ni}, \mathrm{Pb}$, and $\mathrm{Zn}$ in Uruguayan Rice Determined by Atomic Absorption Spectrometry. Atomic Spectroscopy, 27(1), 51-59.
[43] P. Roy, T. Ijiri, H. Okadome, D. Nei, T. Orikasa, N. Nakamura \& T Shiina (2008). Effect of processing conditions on overall energy consumption and quality of rice (Oryza sativa L.). Journal of Food Engineering, $\quad 89(3)$ https://doi.org/10.1016/j.jfoodeng.2008.05.015

[44] M. W. Tenagashaw, G. M. Kenji, E. T. Melaku, S. Huyskens-Keil \& J. N. Kinyuru (2016). Proximate composition and selected functional properties of complementary foods from teff fortified with soybean and orange-fleshed sweetpotato. RUFORUM Working Document Series (ISSN 1607-9345), 14(1), 953-965.

[45] T. P. Trinidad, A. C. Mallillin, R. S. Sagum, D. P. Briones, R. R. Encabo \& B. O. Juliano (2009). Iron absorption from brown rice / brown rice-based meal and milled rice / milled rice-based meal. International Journal of Food Sciences and Nutrition, 60(8), 688-693. https://doi.org/10.3109/09637480701830404.

[46] FAOSTAT statistical database. Rome: Food and Agriculture Organization, 2001.

[47] J. Barron, "Black rice bran, the next superfood? Baseline of Health Foundation. 21ST SEPT." Retrieved from https://jonbarron.org/article/black-rice-bran-next-superfood, 2010.

[48] T. K. Abbey, A. Alhassan, K. Ameyibor, J. W. Essiah, E. Fometu, and M. B. Wiredu, Integrated science for senior secondary schools vol. 75, 76, 451. Accra North, Ghana: Unimax Maxmillan Ltd, 2001.

[49] R. L. Tinsley and P. Emeritus, Increasing rice productivity for the kpong irrigation project. Akuse-Asutsuare, Ghana: Colorado State University ACDI/VOCA Farmer-to-Farmer Program, 2009.

[50] R. K. Singh, P. L. Gautam, S. Saxena, and S. Singh, Scented rice germplasm: Conservation evaluation and utilization. In: Singh, U., S., Singh, R., K., andKhush, G., S., Aromatic rices. New Delxi, Calcutta: Oxford \& IBH Publishing Co. Pvt. Ltd, 2000.FAO, PAN American Health Organization, and WHO, ''Food Handlers Manual Instructions, ' FAO and WHO, Washington, D.C., USA, 2017. 